\title{
MANAJEMEN PENGEMBANGAN KOMPETENSI GURU PAI
}

\author{
Muh. Hambali \\ hambali@pai.uin-malang.ac.id \\ FITK UIN Maulana Malik Ibrahim Malang
}

\begin{abstract}
Development of competence of teachers of PAI is a basic requirement for institutional. Teachers have a variety of names in the perspective of Islam have extended the repertoire of Islamic values and the performance of teachers. Among the names in Islamic religious education is ustads, mu'allim, murabbiy, mursyid, mudarris and muaddib. Each name has a classification of values and functions that impact on the quality of teacher competence PAI. Competence for teachers in need of institutional management capabilities and its sub-systems within the institution. Management is a tool to develop alignment concept of competencies, values and appearance of the teacher. Teachers are part of the institutional system requires management to manage five competence of teachers. Five competencies that are personable, professional, pedagogical, social and leadership. The competence should be the strength of the weakness of teacher competence and competence development it into an opportunity rather than obstacles teachers face external challenges.
\end{abstract}

Key Words: management development, teacher competence of PAI

\section{Abstrak}

Pengembangan kompetensi guru pendidikan agama Islam merupakan kebutuhan dasar bagi kelembagaan. Guru mempunyai ragam nama dalam perspektif khasanah Islam telah menambah nilai-nilai keislaman dan performa guru. Di antara nama dalam pendidikan agama Islam adalah ustadz, mu'allim, murabbiy, mursyid, mudarris dan muaddib. Setiap nama mempunyai klasifikasi nilai dan fungsinya yang berdampak pada kualitas kompetensi guru PAI. Kompetensi bagi guru membutuhkan kemampuan pengelolaan kelembagaan beserta sub-sistem dalam lembaga.Manajemen merupakan alat untuk mengembangkan keselarasan konsep kompetensi, nilai-nilai dan penampilan guru. Guru merupakan bagian dari sistem kelembagaan membutuhkan manajemen yang mengelola lima kompetensi guru. Lima kompetensi itu adalah kepribadian, profesional, pedagogik, sosial dan kepemimpinan.Kompetensi tersebut mesti menjadi kekuatan dari kelemahan pengembangan kompetensi guru dan kompetensi itu menjadi peluang dari pada hambatan guru dalam menghadapi tantangan eksternal.

Kata Kunci: manajemen pengembangan, kompetensi guru PAI

\section{Pendahuluan}

Guru Agama Islam adalah seorang guru biasa disebut dengan ustadz, mu'allim, murabbiy, mursyid, mudarris dan muaddib, yang artinya orang yang memberikan ilmu pengetahuan dengan tujuan mencerdaskan dan membina akhlak peserta didik agar menjadi orang yang berkepribadian baik (Muhaimin, 2005: 44-49).Tanggung jawab guru yang normatif tersebut membutuhkan penjabaran ruang yang operasional agar dapat dilaksanakan oleh organisasiorganisasi sekolah. Tanggung jawab para guru dapat disebut lima kompetensi yang terdapat dalam Undang-Undang Nomor 20 
tahun 2003 tentang Guru dan Dosen dan Peraturan Pemerintah Nomor 19 Tahun 2005 tentang Standar Nasional Pendidikan menuntut reformasi guru untuk memiliki kompetensi, yaitupedagogik, kepribadian, profesional dan sosial. Kompetensi merupakan gambaran hakikat kualitatif perilaku seseorang. Kompetensi merupakan kapasitas untuk melakukan sesuatuyang dihasilkan dari proses belajar. Selama proses belajar seorang guru semestinya menunjukkan kemampuannya menjadi seorang pendidik. Kompetensi pendidik perlu bersendikan pada prinsip keguruan. Prinsip keguruan itu dapat berupa: (1) kegairahan dan kesediaan untuk mengajar seperti memerhatikan: kesedian, kemampuan, pertumbuhan, dan perbedaan peserta didik; (2) membangkitkan gairah peserta didik; (3) menumbuhkan bakat dan sikap peserta didik yang baik; (4) mengatur proses belajar mengajar yang baik; (5) memerhatikan perubahan-perubahan kecenderungan yang memengaruhi proses mengajar; dan (6) adanya hubungan manusiawi dalam proses belajarmengajar.

Muhaimin (2003: 209-213), memetakan tugas kompetensi pendidik dalam perspektif Islam sebagaimana dalam tabel berikut:

Tabel 1. Istilah Pendidik

\begin{tabular}{|l|l|l|}
\hline NO. & $\begin{array}{c}\text { ISTILAH } \\
\text { PENDIDIK }\end{array}$ & \multicolumn{1}{|c|}{ TUGAS KOMPETENSI PENDIDIK DALAM PENDIDIKAN ISLAM } \\
\hline 1. & Ustadz & $\begin{array}{l}\text { Orang yang komitmen terhadap profesionalisme, yang melekat } \\
\text { pada dirinya sikap dedikatif, komitmen terhadap mutu proses } \\
\text { dan hasil kerja, serta sikap continous improvement. }\end{array}$ \\
\hline 2. & Mu'allim & $\begin{array}{l}\text { Orang yang menguasai ilmu dan mampu mengembangkannya } \\
\text { serta menjelaskan fungsinya dalam kehidupan, menjelaskan } \\
\text { dimensi teoritis dan praktisnya, sekaligus melakukan "transfer } \\
\text { ilmu/pengetahuan, internalisasi, serta impelementasi (amaliah) } \\
\text { secara terpadu. }\end{array}$ \\
\hline 3. & Murabbi & $\begin{array}{l}\text { Orang yang mendidik dan menyiapkan peserta didik agar mampu } \\
\text { berkreasi serta mampu mengatur dan memelihara hasil } \\
\text { kreasinya untuk tidak menimbulkan malapetaka bagi dirinya, } \\
\text { masyarakat dan alam sekitarnya. }\end{array}$ \\
\hline 4. & Mursyid & $\begin{array}{l}\text { Orang yang mampu menjadi model atau sentral identifikasi diri } \\
\text { atau menjadi pusat anutan, teladan dan konsultan bagi peserta } \\
\text { didik. }\end{array}$ \\
\hline 5. & Mudarris & $\begin{array}{l}\text { Orang yang memiliki kepekaan intelektual dan informasi serta } \\
\text { memperbarui pengetahuan dan keahliannya secara } \\
\text { berkelanjutan, dan berusaha mencerdaskan peserta didiknya, } \\
\text { memberantas kebodohan mereka, serta melatih keterampilan } \\
\text { sesuai dengan bakat, minat dan kemampuannya. }\end{array}$ \\
\hline 6. & Mu'addib & $\begin{array}{l}\text { Orang yang mampu menyiapkan peserta didik untuk } \\
\text { bertanggung jawab dalam membangun peradaban yang } \\
\text { berkualitas di masa depan. }\end{array}$ \\
\hline
\end{tabular}

Sumber: Muhaimin (2003) 
Berdasarkan tabel di atas, tugas pendidik mempunyai tanggung jawab sangat mulia jika dapat terlaksana dengan baik di lembaga pendidikan.Profesionalisme pendidik sangat penting untuk mendorong pelaksanaan tugas keguruan yang mempunyai kompleksitas dalam pelaksanaan di sekolah.

Gurumenjadi pendidik profesional membutuhkan berbagai kompetensi keguruan. Kompetensi dasar bagi guru didasarkan pada tahapan kepekaan terhadap bobot potensi dasar dan kecenderungan yang dimilikinya. Kompetensi membutuhkan kemampuan persiapan para guru untuk menguasai pengetahuan, keterampilan dan kemampuan kusus yang terkait dengan profesi bidang mata pelajaran keguruan. Kompetensi membangun ketrampilan dalam belajar-mengajar di kelas. Guru dianjurkan meningkatkan kemampuannya agar memenuhi syarat guru yang profesional. Kompetensi yang harus dimiliki oleh guru berdasarkan Undangundang Nomor 14 Tahun 2005 tentang Guru dan Dosen pada Bab IV (Udin Syaefudin Saud, 2009: 49). Pasal 10 ayat 91, yang menyatakan bahwa " Kompetensi guru meliputi kompetensi pedagogik, kompetensi kepribadian, kompetensi sosial, dan kompetensi profesional yang diperoleh melalui pendidikan profesi".

Kompetensi berasal dari kata competency, yang berarti kemampuan atau kecakapan (Rusman, 2010: 70). Menurut kamus Bahasa Indonesia, kompetensi dapat diartikan (kewenangan) kekuasaan untuk menentukan atau memutuskan suatu hal (Moch. Uzer Usman, 2005: 14).Beberapa makna dari istilah kompetensi, yaitu :

1. Kompetensi mengacu pada kemampuan melaksanakan sesuatu yang diperoleh melalui pendidikan.
Kompetensi menunjukkan penampilan dan perbuatan yang rasional untuk memenuhi spesifikasi tertentu dalam melaksanakan tugastugas kependidikan (Hamzah Uno, 2012: 61).

2. Competence is broad capacities as fully human attribute. Compentence is supposed to include all "qualities of personal effectiveness that are required in the workplace", it is certain that we have here a very diverse set of qualities indeed: attitude, motives, interest, personal attunements of all kinds, perceptiveness, receptivity, openness, creativity, social skill generally, interpersonal maturity, kinds of personal identification, etc,- as well as knowledge, understandings, action and skills(Hamzah Uno, 2012: 62).

3. Kompetensi adalah menggambarkan kualifikasi atau kemampuan seseorang, baik yang kualitatif maupun kuantitatif (Kunandar, 2007: 51).

4. Kompetensi merupakan suatu tugas yang memadai atas kepemilikan pengetahuan, keterampilan dan kemampuan yang dituntut oleh jabatan seseorang (Roestiyah N.K., 1989: 4)

5. Kompetensi juga berarti sebagai pengetahuan, keterampilan dan nilainilai dasar yang direfleksikan dalam kebiasaan berpikir dan bertindak. (Kunandar, 2007: 52).

Pengertian kompetensi ini relasi dengan profesi guru. Kompetensi guru mengandung arti kemampuan seseorang guru dalam melaksanakan kewajibankewajiban secara bertanggung jawab dan atau kemampuan dan kewenangnan guru dalam melaksanakan profesi keguruannya (Kunandar, 2007: 
55). Guruadalah orang yang bertugas mencerdaskan kehidupan bangsa dalam semua aspeknya, baik spiritual, emosional, intelektual, fisikal, finansial maupun aspek lainnya. Dalam bahasa teknik edukatif, guru terkait dengan kegiatan untuk mengembangkan peserta didik dalam ranah kognitif, afektif dan psikomotorik (Moh. Roqib, 2011: 22).

Pengertian kompetensi guru pendidikan agama Islam yakni pendidikan penting bagi kehidupan manusia, terutama dalam mencapai ketentraman batin dan kesehatan mental. Agama Islam merupakan bimbingan hidup yang paling baik, pencegah perbuatan salah yang paling ampuh, pengendali moral yang tiada taranya. Maka kompetensi guru agama Islam adalah kewenangan untukmenentukan pendidikan agama Islam yang akan diajarkan pada jenjang tertentu di sekolah tempat guru tersebut mengajar(Zakiyah Daradjat, 2010: 95).

Kompetensi diartikan oleh Cowell,yang dikutip oleh Anshori(2010: 59), sebagai suatu keterampilan yang bersifat aktif. Kompetensi dikategorikan mulai dari tingkat dasar hingga lebih kompleks yang pada gilirannya akan berhubungan dengan proses penyusunan bahan atau pengalaman belajar yang lazimnya terdiri dari( Anshori, 2010: 59: (1) Penguasaan minimal kompetensi dasar; (2) Praktik kompetensi dasar; (3) Penambahan penyempurnaan atau pengembangan terhadap kompetensi atau ketrampilan.

Ketiga proses tersebut dapat terus berlanjut selama masih ada kesempatan untuk melakukan penyempurnaan atau pengembangan kompetensinya. Kompetensi merupakan satu-kesatuan yang utuh yang menggambarkan potensi, pengetahuan, keterampilan, dan sikap yang dinilai, yang terkait dengan profesi tertentu berkenaan dengan bagian-bagian yang dapat diaktualisasikan dan diwujudkan dalam bentuk tindakan atau kinerja untuk menjalankan profesi tertentu.

Kompetensi guru mengandung arti kemampuan seseorang guru dalam melaksanakan kewajiban-kewajiban secara bertanggung jawabguru dalam melaksanakan profesi keguruannya.Jadi, pengertian kompetensi guru adalah seperangkat penguasaan kemampuan yang harus ada dalam diri guru agar dapat mewujudkan kinerjanya secara tepat dan efektif.

\section{Pengembangan kompetensi guru agama Islam}

Guruadalah orang yang

bertanggung jawab terhadap perkembangan peserta didik dalam pengajaran, pembinaan dan pelatihan. Aspek pendidikan itu mencakup seluruh potensi peserta didik yang mencakup potensi afektif, kognitif dan psikomotorik.Seorang guru mempunyai defnisi pendidik kodrat dan pendidik jabatan.Dua aspek itu merupakan dua ruang lingkup tanggung jawab guru yang perlu mempunyai penjiwaan sebagai pendidik.Pendidik kodrat artinya setiap orang dewasa mempunyai keluarga yang sepantasnya memberikan pendidikan pada keluarga sebelum mendidik di luar keluarganya. Sebagaimana dapat dibaca dalam Surah At Tahrim (66) ayat 6: "Hai orang-orang yang beriman, perihalah dirimu dan keluargamu dari api neraka yang bahan bakarnya adalah manusia dan batu; penjaganya malaikat-malaikat yang kasar, yang keras, yang tidak mendurhakai Allah terhadap apa yang diperintahkanNya kepada mereka dan selalu mengerjakan apa yang diperintahkan. “

Ini artinya bahwa setiap orang tua dalam keluarganya mempunyai 
tanggung jawab mendidik tanpa harus berpendidikan formal tinggi.Orang tua mesti mesti meningkatkan kualitas diri agar mampu bersinergi dengan visi dan misi sekolah.Orang tua merupakan bagian dari warga sekolah perlu meningkatkan keahlian mendidik anaknya dan keluarganya.Hal ini merupakan tanggung jawab kodrati bagi setiap pemimpin keluarga.

$$
\text { Pendidikan membutuhkan }
$$

keterlibatan lingkungan

masyarakat.Masyarakat merupakan bagian penting diharapkan berpartisipasi dalam pengembangan peserta didik.Sedangkan guru yang bertanggung jawab di pendidikan formal yang mmempunyai jabatan dan kompetensi.Kompetensi guru tidak sebatas pengetahuan dan tanggung jawab setiap orang, namun guru membutuhkan kemampuan kusus melalui jalur formal di lembaga pendidikan atau dapat di sebut LPTK (Lembaga pendidikan Tenaga Kependidikan). Gurudalam jabatan membutuhkan kemampuan kusus yang kualitasnya membutuhkan perencanaan sistematis. Pada hakikatnya, guru dalam jabatan adalah dapat membantu orang tua dalam mendidik anak karena ia memiliki berbagai keterbatasan.

Kompetensi berhubungan dengan interaksi belajar mengajar dalam proses pembelajaran. Seseorang guru menyampaikan materi pelajaran jika tidak disertai dengan kompetensi seperti penguasaan bahan, begitu juga dengan pemilihan dan penggunaan metode yang tidak sesuai dengan materi akan menimbulkan kebosanan dan mempersulit pemahaman belajar siswa. Dengan demikian, kompetensiguru sangat mendukung dalam rangka merangsang motivasi belajar siswa dan sekaligus tercapainya interaksi belajar mengajar sebagai mestinya. yang Proses interaksi belajar mengajar perbuatan guru dan siswa atas timbal balik yang langsung dalam situasi pendidkan untuk mencapai tujuan tertentu. Intraksi guru dengan siswa bukan hanya dalam penguasaan bahan ajran, tetapi juga dalam penerimaan nilainilai, pengembangan sikap serta mengatasi kesulitaan-kesulitan yang di hadapi oleh siswa.intraksi belajar mengajar dari guru kepada peserta didik dalam rangka menimbulkan motivasi belajar siswa, guru bukan hanya saja sebagai pelatih dan pengajar tetapi juaga sebagai pendidik dan pembingbing.

Kemampuan profesionalitas guru menurut Mohammad Uzer Usman (2005) meliputi berikut ini:

1. Menguasai landasan kependidikan

2. Menguasai bahan pengajaran

3. Menyusun program pengajaran

4. Melaksanakan program pengajaran

5. Menilai hasil belajar mengajar yang telah dilaksanakan

Berdasarkan pengertian di atas, maka seorang guru profesional adalah guru yang mempunyai strategi mengajar, menguasai bahan, mampu menyusun program maupun membuat penilaian hasil belajar yang tepat.Untuk dapat melaksanakan perannya, guru harus mempunyai kompetensi sebagai modal dasar dalam mengemban tugas dan kewajibannya. Profesionalitas merupakan kata yang intensif pada guru. Gurumenunjukkan kinerja yang profesionalitas merupakan keniscayaan dalam menjalankan tugas pengajaran, pelatihan, pembimbingan dan pengevalusian. Kriteria profesionalitas adalah kemampuan menunjukkan etos dan dedikasi sebagai pendidik.Sertifikat pendidik merupakan jawaban meningkatkan kinerja organisasi profesi guru dan standarisasi guru yang 
menjalankan tugas pokok di lembaga pendidikan.

Hal ini dapat diperkuat oleh Nahlawi(1989: 239-244)bahwa seorang pendidik mempunyai karakteristik berikut ini:

a. Setiap pendidik harus memiliki sifat rabbani, yaitu memiliki ketaatan kepada Tuhan yang Maha Esa.

b. Seorang pendidik hendaknya menyempurnakan sifat rabbaniahnya dengan keikhlasan.

c. Seorang pendidik hendaknya mengajarkan ilmunya dengan sabar.

d. Seorang pendidik harus memiliki kejujuran dengan menerapkan apa yang dia ajarkan dalam kehidupan pribadinya.

e. Seorang pendidik harus senantiasa meningkatkan wawasan dan pengetahuannya.

f. Seorang pendidik harus cerdik dan terampil dalam menciptakan metode pengajaran yang variatif serta sesuai dengan situasi dan materi pelajaran.

g. Seorang pendidik harus mampu bersikap tegas dan meletakkan sesuatu sesuai proporsinya.

h. Seorang pendidik dituntut untuk memahami psikologi anak didiknya.

i. Seorang pendidik dituntut untuk peka terhadap fenomena kehidupan sehingga dia mampu memahami berbagai kecenderungan dunia beserta dampak dan akibtanya terhadap anak didik.

j. Seorang pendidik dituntut untuk memiliki sikap adil terhadap seluruh anak didiknya.

Karakteristik pendidik di atas merupakan dasar yang melekat dan mesti mendapat tempat secara tepat.Pendidik mempunyai peran dan tugas memberikan dorongan pengawasan, pembinaan terhadap kedisiplinan anak agar patuh terhadap aturan sekolah.Tugas ini mempunyai kaitan dalam meningkatkan pertumbuhan dan perkembangan anak untuk memperoleh pengalamanpengalaman pembelajaran.Oleh karena itu, Pendidik sebagai guru membutuhkan kompetensi yang tinggi untuk melaksanakan tugas-tugas dasar kemampuan mengajar dan mengevaluasi. Sebagaimana pendapat berikut ini (Whina Sanjaya, 2007: 27), yaitu 1) guru harus merencanakan tujuan dan mengidentifikasi kompetensi yang hendak dicapai; 2) Guru harus melihat keterlibatan peserta didik dalam pembelajaran dan yang paling penting bahwa peserta didik melaksanakan kegiatan belajar itu tidak hanya secara jasmaniah; 3) guru harus memaknai kegiatan belajar; dan 4) guru harus melaksanakan penilaian.

\section{Kompetensi guru pendidikan agama Islam (GPAI)}

Kompetensi yang dimaksud adalah (Omar Hamalik, 2002: 36):

1) Kompetensi personal, artinya seorang guru harus memiliki kepribadian yang mantap yang patut untuk diteladani.

2) Kompetensi profesional, artinya seorang guru harus memiliki pengetahuan yang luas, mendalam dari bidang studi yang diajarkannya, memilih dan menggunakan berbagai metode mengajar dalam proses belajara mengajar yang diselenggarakannya.

3) Kompetensi sosial, artinya seorag guru harus mampu berkomunikasi baik dengan siswa, sesama guru maupun masyarakat luas.

4) Kompetensi Pedagogik yang meliputi pemahaman terhadap peserta didik serta suasana di kelas. 
5) Kompetensi kepemimpinan. Kompetensi ini adalah kompetensi yang harus dimiliki guru PAI terkait dalam hal mempengaruhi orang lain. Masalah kepemimpinan akan di bab tersendiri.

\section{Kompetesi pedagogik}

Kompetensi pedagogik adalah kemampuan yang harus dimiliki guru berkenaan dengan karakteristik peserta didik dilihat dari berbagai aspek fisik, moral, sosial, kultural,emosional dan intelektual. Hal tersebut berimplikasi bahwa seorang guru harus mampu menguasai teori belajar dan prinsipprinsip pembelajaran yang mendidik karena peserta didik memiliki karakter, sifat, dan keterkaitan yang berbeda. Berkenaan dengan pelaksanaan kurikulum, seorang guru harus mampu mengembangkan kurikulum di tingkat satuan pendidikan masing-masing dan disesuaikan dengan kebutuhan lokal. Kompetensi pedagogik merupakan kemampuan guru dalam pengelolaan pembelajaran peserta didik yang sekurang-kurangnya meliputi (Anshori, 2010: 61):

1. Pemahaman wawasan atau landasan kependidikan

2. Pemahaman terhadap peserta didik

3. Pengembangan kurikulum atau silabus

4. Perancangan pembelajaran

5. Pelaksanaan pembelajaran yang mendidik dan dialogtis

6. Pemanfaatan teknologi pembelajaran

7. Evaluasi hasil belajar

8. Pengembangan peserta didik untuk mengaktualisasikan berbagai kompetensi yang dimilkinya.

\section{Kompetensi kepribadian}

Pendidikan adalah proses yang direncanakan agar semua berkembang melalui proses pembelajaran. Gurusebagai pendidik dapat mempengaruhi kearah proses pembelajaran dengan tata nilai yang dianggap baik dan berlaku dalam masyarakat. Guru harus memiliki kedisiplinan yang berstandar kode etik profesi agar berdampak pada sikap mental, watak dan kepribadian peserta didik yang kuat. Guru dituntut membelajarkan peserta didik untuk disiplin diri, membaca, mencintai buku, menghargai waktu dan sadar tata tertib.

Kesadaran guru tergambar dalam personifikasi pribadi yang unggul merupakan syarat mutlak menjadi guru.Keunggulan kepribadian menunjukkan nilai dan sikap yang dapat diterima oleh organisasi profesi dan masyarakat madrasah.Kapasitas kepribadian perlu menunjukkan keteladanan di dalam madrasah maupun di luar madrasah.Keteladanan merupakan dasar dalam penciptaan kelembagaan yang kondusif.Kompetensi kepribadian adalah sejumlah cakupan prasyarat yang harus dimiliki oleh guru dalam diri dan kepribadiannya. Kompetensi ini sekurangkurangnya mencakup (Anshori, 2010: 61):

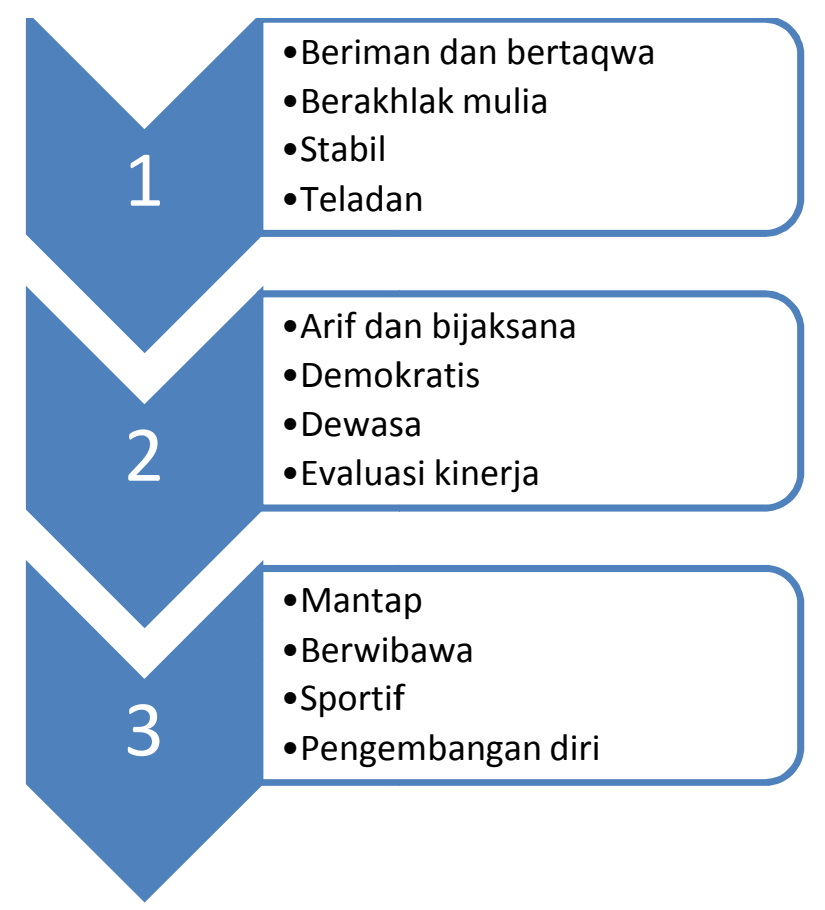


Setiap guru PAI semestinya menunjukkan sifat ini agar dapat menumbuhkan kompetensi yang ingin dicapai oleh lembaga pendidikan.Sebagaimana juga, seorang guru membutuhkan kesungguhan dalam menjalankan tugas guru di dalam pendidikan agama Islam. Sifat tersebut antara lain (Anshori, 2010: 63):

1. Zuhud dalam arti tidak mengutamakan keridlaan Allah semata.

2. Kebersihan guru harus senantiasa dijaga.

3. Ikhlas dalam pekerjaan.

4. Pemaaf

5. Seorang guru merupakan bapak/ibu, saudara, dan sahabat sebelum ia menjadi guru.

6. Seorang guru harus mengetahui tabiat murid

7. Menguasai materi pelajarannya

8. Kreatif dalam memberikan pengajaran kepada siswanya, sehingga siswa mudah dalam menerima transfer pemikiran yang diberikan.

9. Harus menaruh kasih sayang terhadap murid dan memperhatikan mereka seperti terhadap anak sendiri

10. Memberikan nasihat kepada murid dalam setiap kesempatan

11. Mencegah murid dari akhlak yang tidak baik dengan jalan sindiran, terus terang, halus dengan tidak mencela.

12. Guru harus memperhatikan tingkat kecerdasan muridnya dan berbicara dengan mereka dengan kadar akalnya, termasuk di dalamnya berbicara dengan bahasa mereka.

13. Tidak menimbulkan kebencian pada murid terhadap suatu cabang ilmu yang lain
14. Guruharus mengamalkan ilmu serta menyelaraskan kata dengan perilaku.

Seorang guru membutuhkan nilai-nilai keteladanan dan kesederhanaan dalam mengkontruksi motivasi peserta didik.Motivasi peserta didik memiliki gambaran terhadap kewajiban sekolah jika nilai sikap guru dapat mengkondisikan suasana pembelajaran.Nilai dan tradisi ikhlas dan tanggung jawab menjadi penting pada ranah afektif bagi guru. Guru pendidikan agama Islam yang berkepribadian merupakan dasar disseminasi nilai, norma dan tradisi yang mencirikan zuhud. Hal ini dikarenakan zaman terus berubah, permasalahan bertambah, dan tantangan pun variatif, tidak semata pemimpin di sekolah untuk merespon persoalan tersebut harus terus dikembangkan hingga pada titik yang paling sempurna.Bila diterjemahkan lebih jauh.Guru berkepribadian adalah orang dalam organisasi profesi yang tidak mengutamakanjabatan semata, namun ia mampu memberikan manfaat bagi orang lainatau bagi organisasi profesi. Setiap jenis organisasi profesi membutuhkan kinerja totalitas agar mencapai perubahan arti fungsional yang lebih besar bagi masyarakat.

$$
\text { Organisasi profesi guru }
$$
mempunyai peran mulia yang tertulis dalam undang-undang dan peraturan lainnya. Ini artinya kedudukan guru secara normatif mendapatkan ruang yang tinggi dalam masyarakat, namun ini belum berbanding lurus dengan beberapa kasus yang dihadapi oleh para guru, misalnya guru mendapatkan hak tunjangan profesi guru di beberapa di daerah tidak sama pendapatannya dalam satu tahunnya walaupun mereka dari kementerian yang sama. Kenyataan ini tidak menyebabkan para guru menurunkan motivasi mengajar 
dan menjaga nilai-nilai unggul, yaitu profesional dan ikhlas dalam menjalankan profesinya.Oleh karena itu dapat disebut guru tersebut mempunyai kepribadian matang.

\section{Kompetensi Sosial}

Kompetensi sosial adalah keahlian guru melakukan komunikasi, bekerja sama, bergaul simpatik dan mempunyai jiwa yang menyenangkan. Keahlian guru itu harus mampu beradaptasi dengan warga sekolah. Kemampuan inin juga akan memperkuat iklim pembelajaran yang kondusif antara guru dengan murid dan guru dengan wali murid. Apabila ini terusmenerus terkelola dengan baik berdampak pada kemajuan motivasi belajar bagi peserta didik.Struktur lingkungan belajar peserta didik membutuhkan peran guru.Gurumerupakan motor utama menciptakan interaksi yang aktif bukan pasif. Oleh karena itu kompetensi sosial membutuhkan keahlian motorik, bukan sekedar ahli konsepnya.Pengalaman guru mempunyai pengaruh besar menciptakan lingkungan sosial yang terstruktur.

Kompetensi sosial adalah kebutuhan dasar guru untuk mencapai keunggulan guru di sekolah maupun di luar sekolah. Guru berperan untuk menciptakan kelompok profesi guru yang mampu mendorong hubungan guru dan murid tidak sekedar pembelajaran, namun hubungan itu juga terjadi di lingkungan masyarakat luas. Untuk itu membutuhkan kinerja guru yang kuat dalam memposisikan secara stratetis.Kriteria kinerja guru dalam kaitannya dengan kompetensi sosial. Kompetensi sosial merupakan kemampuan guru sebagai bagian dari masyarakat yang sekurangkurangnya meliputi keahlian:

1. Beradaptasi ditempat bertugas si seluruh Republik Indonesia yang memiliki keragagaman sosial budaya.

2. Menggunakan teknologi komunikasi dan informasi secara fungsional;

3. Berkomunikasi dengan komunitas profesi sendiri dan profesi lain secara lisan dan tulisan atau bentuk lain.

4. Berkomunikasi secara efektif, empatik dan santun dengan sesame pendidik, tenaga kependidikan, orang tua, dan masyarakat.

5. Menerapkan prinsip persaudaraan sejati dan semangat kebersamaan.

Dengan kompetensi tersebut, berdampak langsung hubungan madrasah/sekolah dengan masyarakat akan berjalan dengan lancar, sehingga jika ada keperluan dengan orang tua peserta didik, para guru tidak akan mendapat kesulitan.

\section{Kompetensi Profesional}

Kompetensi profesional adalah kemampuan yang harus dimiliki guru dalam perencanaan dan pelaksanaan proses pembelajaran. Gurumempunyai tugas untuk mengarahkan kegaiatan belajar peserta didik untuk mencapai tujuan pembelajaran. Untuk itu guru dituntut mampu menyampaikan bahan pelajaran. Dalam menyampaikan pembelajaran, guru mempunyai peranan dan tugas sebagai sumber materi yang tidak pernah kering dalam mengelola proses pembelajaran. Kegiatan mengajarnya harus disambut oleh peserta didik sebagai suatu seni pengelolaan proses pembelajaran yang diperoleh melalui latihan, pengalaman, dan kemauan belajar yang tidak pernah putus.

\section{Kompetensi}

profesional merupakan kemampuan guru dalam menguasai bidang ilmu pengetahuan, 
teknologi, dan budaya yang diampunya yang sekurang-kurangnya meliputi penguasaan dalam: a) materi pelajaran secara luas dan mendalam sesuai dengan standar isi program satuan pendidikan, mata pelajaran dan kelompok mata pelajaran yang akan diampu, b) konsep dan metode disiplin keilmuan, teknologi, atau seni yang relavan, yang secara konseptual menaungi atau koheren dengan program satuan pendidikan, mata pelajaran, dan kelompok mata pelajaran yang akan diampu.

Kemampuan yang harus dimiliki pada dimensi komepetensi profesional dapat dicermati dari aspek-aspek berikut ini.

1. Menguasai materi, struktur, konsep dan pola pikir keilmuan yang mendukung mata pelajaran.

2. Menguasai standar kompetensi dan kompetensi dasar mata pelajaran.

3. Mengembangkan materi pelajaran yang diampu secara kreatif.

4. Mengembangkan keprofesionalan secara berkelanjutan dengan melakukan tindakan reflektif.

5. Memanfaatkan teknologi informasi dan komunikasi untuk berkomunikasi dan mengembangkan diri.

Untuk mengukur kompetensi guru melalui uji kompetensi guru dapat dirumuskan profil guru kompetensinya.Kondisi nyata itulah yang menjadi dasar peningkatan kompetensi guru.Dengan demikian, tujuan uji kompetensi adalah menilai dan menetapkan apakah guru sudah kompeten atau belum dilihat dari standar kompetensi yang diujikan.Pelaksanaan uji kompetensi dilakukan dengan menggunakan prinsip-prinsip seperti berikut ini.

1. Valid, yaitu menguji apa yang seharusnya dinilai atau diuji dan bukti-bukti yang dikumpulkan harus mencukupi serta terkini dan asli.

2. Reliabel, yaitu uji kompetensi bersifat konsisten, dapat menghasilkan kesimpulan yang relatif sama walaupun dilakukan pada waktu, tempat dan asesor yang berbeda.

3. Fleksibel, yaitu uji kompetensi dilakukan dengan metode yang disesuaikan dengan kondisi peserta serta tempat uji kompetensi.

4. Adil, yaitu uji kompetensi tidak boleh ada diskriminasi terhadap guru, dimana mereka harus diperlukan sama sesuai dengan prosedur yang ada dengan tidak melihat dari kelompok mana dia berasal.

5. Efektif dan efisien, yaitu uji kompetensi tidak mengorbankan sumber daya dan waktu yang berlebihan dalam melaksanakan uji kompetensi sesuai dengan unjuk kerja yang ditetapkan. Uji kompetensi sebisa mungkin dilaksanakan di tempat kerja atau dengan mengorbankan waktu dan biaya yang sedikit.

Tingkat kualitas kompetensi profesi seseorang itu tergantung pada tingkat penguasaan kompetensi kinerja (performance competence) sebagai ujung tombak serta tingkat kemantapan penguasaan kompetensi kepribadian (values and attitudes competencies) sebagai landasan dasarnya, maka implikasinya ialah bahwa dalam upaya penembangan profesi dan perilaku guru itu keduannya (aspek kinerja dan kepribadian) seyogyanya diindahkan keterpaduannya secara proporsional. Dengan demikian maka identitas dan jati diri seorang tenaga kependidikan yeng profesional pada dasarnya akan ditandai oleh tercapainya tingkat kematangan kepribadian yang 
mantap dalam menampilkan kinerja profesinya yang prima dengan penuh semangat pengabdian bagi kemaslahatan umat manusia sesuai dengan bidang keahliannya (Udin Syaefudin Saud, ,2009: 132).

Tujuan adanya standar kompetensi guru adalah sebagai jaminan dikuasainya tingkat kompetensi minimal oleh guru sehingga yang bersangkutan dapat melakukan tugasnya secara profesional, dapat dibina secara efektif dan efisien serta dapat melayani pihak yang berkepentingan terhadap proses pembelajaran dengan sebaik-baiknya sesuai dengan bidang tugasnya.

Adapun manfaat disusunya standar kompetensi guru ini adalah sebagai acuan pelaksanaan uji kompetensi, penyelenggaraan diklat, dan pembinaan, maupun acuan bagi pihak yang berkepentingan terhadap kompetensi guru untuk melakukan evaluasi, pengembangan bahan ajar dan sebagainya bagi tenaga kependidikan. Kompetensi tersebut diperlukan adanya indikatorindikator yang dapat teramati dan terukur. Dengan hasil pengamatan dan pengukuran itulah tingkatan penguasaan (mastery and proficiencymastery and proficiency) dalam jenis kompetensi tertentu akan dapat diketahui dengan mengacu kepada kriteria keberhasilan kinerja minimal yang dapat diterima (the minimal acceptable performance) yang telah ditetapkan (disepakati) terlebih dahulu.

Dalam rangka mendukung terwujudnya suasana proses belajar mengajar yang berkualitas di lembaga pendidikanmembutuhkan adanya profesionalitas. Karakteristik guru yang profesionalitas sedikitnya ada lima karakteristik dan kemampuan profesionalitas guru yang harus dikembangkan, yaitu (Muh Uzer Usman,1981):

a. menguasai kurikulum

b. menguasai materi semua mata pelajaran

c. terampil menggunakan multi metode pembelajaran

d. memiliki komitmen yang tinggi terhadap tugasnya

e. memiliki kedisiplinan dalam arti yang seluas-luasnya Guru yang profesional membutuhkan langkah-langkah yang relevan.Sebelum itu, seorang guru harus memiliki kriteria-kriteria yang ditetapkansebagaidasarpembentukan guru profesional. Berdasarkan UU No. 14 tahun 2005 pasal 8 menyatakan bahwa guru wajib memiliki kualifikasi akademik, kompetensi, sertifikat pendidik, sehat jasmani dan rohani, serta memiliki kemampuan untuk mewujudkan pendidikan nasional. Kemudian pasal 9 menyatakan kualifikasi akademik sebagaimana yang dimaksud dalam pasal 8 diperoleh melalui pendidikan tinggi program sarjana atau program diploma empat.Penegasan dari UU ini menyatakan bahwa untuk mejadi seorang guru, minimal harus berpendidikan sarjana atau diploma empat. Sedangkan menurut Sulani, syarat pokok seorang guru adalah:

a. syarat syakhsiyah (memiliki kepribadian yang dapat diandalkan)

b. syarat ilmiah (memiliki ilmu pengetahuan yang mumpuni)

c. syarat idhafiyah (mengetahui, menghayati dan menyelami manusia yang dihadapinya, sehingga dapat menyatukan dirinya untuk membawa anak didik menuju tujuan yang ditetapkan).

Kompetensi guru di Indonesia telah pula dikembangkan oleh Proyek 
Pembinaan Pendidikan.Guru (P3G) Departemen Pendidikan dan Kebudayaan.Pada dasarnya kompetensi guru menurut P3G bertolak dari analisis tugas-tugas seorang guru, baik sebagai pengajar, pembimbing, maupun sebagai administrator kelas. Ada sepuluh kompetensi guru menurut P3G (Rusman, 2010: 51), yaitu (1)Menguasai bahan; (2) Mengelola program belajar mengajar; (3) Mengelola kelas (4); Menggunakan media atau sumber belajar; (5) Menguasai landasan kependidikan; (6)Mengelola interaksi belajar mengajar; (7) Menilai prestasi belajar; (8) Mengenal fungsi dan layanan bimbingan penyuluhan; (9) Mengenal dan menyelenggarakan administrasi sekolah; dan (10) Memahami dan menafsirkan hasil penelitian guna kepeluan pengajaran.

Delapan dari sepuluh kompetensi yang disebutkan tersebut, lebih diarahkan kepada kompetensi guru sebagai pengajar.Dapat disimpulkan pula bahwa kesepuluh kompetensi tersebut hanya mencakup dua bidang kompetensi guru yakni kompetensi kognitif dan kompetensi perilaku.Kompetensi sikap, khususnya sikap profesional guru, tidak tampak. Untuk keperluan analisis tugas guru sebagai pengajar, maka kompetensi kinerja profesi keguruan (generic teaching competencies) dalam penampilan aktual dalam proses belajar mengajar, minimal memiliki empat kemampuan, yakni, (1)Merencanakan proses belajar mengajar; (2) Melaksanakan dan memimpin/mengelola proses belajar mengajar; (3) Menilai kemajuan proses belajar mengajar; dan (4) Menguasai bahan pelajaran.

Penjelasan di atas bahwa makna profesionalitas merupakan bagian dari totalitas kepribadian guru. Artinya, profesionalisasi harus dimulai sejak dini, yang memerlukan waktu cukup lama serta terus ditelusuri proses perkembangannya. Profesionalitas guru menghendaki kematangan pribadi. Hal ini menyangkut adanya kesiapan seorang guru untuk melakukan interaksi, komunikasi, melaksanakan bimbingan dan penyuluhan, pengadministrasian, penelitian, penguasaan materi pelajaran yang akan disampaikan di kelas, serta kemampuan untuk melakukan evaluasi dan reevaluasi sehingga tugas profesionalitas dapat dilakukan secara maksimal dan terarah.

Menurut Mukhtar (2003: 98) bahwa dimensi dan indikator profesionalitas seorang pendidik dapat ditampilkan dalam tabel berikut ini: 
Tabel 2. Dimensi dan Indikator Profesionalitas Seorang Pendidik

\begin{tabular}{|c|c|}
\hline Dimensi & Indikator \\
\hline 1. Kompetensi & $\begin{array}{l}\text { a. Kompetensi terhadap karier } \\
\text { b. Kompetensi terhadap pekerjaan } \\
\text { c. Kompetensi kepada setiap orang }\end{array}$ \\
\hline 2. Tanggung jawab & $\begin{array}{l}\text { a. Tanggung jawab terhadap pekerjaan. } \\
\text { b. Tanggung jawab terhadap karier. } \\
\text { c. Berientasi pada pelayanan stakeholder. } \\
\text { d. Bekerja sesuai prioriitas. } \\
\text { e. Tanggung jawab sosial. } \\
\text { f. Tanggung jawab moral } \\
\text { g. Tanggung jawab keilmuan. }\end{array}$ \\
\hline 3. Keterbukaan & $\begin{array}{l}\text { a. Orientasi terhadap dunia luar. } \\
\text { b. Terbuka terhadap ide-ide baru. }\end{array}$ \\
\hline $\begin{array}{l}\text { 4. Orientasi reward } \\
\text { atau punishment }\end{array}$ & $\begin{array}{l}\text { a. Memiliki kepastian upah atau gaji. } \\
\text { b. Memiliki status yang jelas. } \\
\text { c. Orientasi prastise. } \\
\text { d. Menghargai atau memiliki kode etik. }\end{array}$ \\
\hline $\begin{array}{l}\text { 6. Kemampuan atau } \\
\text { kreativitas }\end{array}$ & $\begin{array}{l}\text { a. Mampu dan memiliki perilaku pamong. } \\
\text { b. Mengembangkan norma kolaborasi. } \\
\text { c. Mampu berdiskusi mengenai strategi baru. } \\
\text { d. Mampu mengajar. } \\
\text { e. Mampu memecahkan masalah. } \\
\text { f. Mampu menganalisis data. } \\
\text { g. Mampu meningkatkan strategi. } \\
\text { h. Pengendalian risiko. } \\
\text { i. Mampu menghadapi setiap manusia yang berbeda. } \\
\text { j. Mampu saling mendorong. } \\
\text { k. Memiliki keahlian khusus. } \\
\text { l. Memiliki kompetensi. }\end{array}$ \\
\hline
\end{tabular}

Sumber: Mukhtar (2003)

Selain itu, guru yang profesional harus mempunyai kompetensi. Untuk dapat menjadi seorang guru yang memiliki kompetensi, maka diharuskan memiliki kemampuan untuk mengembangkan tiga aspek kometensi yang ada pada dirinya yaitu:

1. Kompetensi pribadi adalah sikap pribadi guru berjiwa pancasila yang mengutamakan budaya bangsa Indonesia, yang rela berkorban bagi kelestarian bangsa dan negaranya.
2. Kompetensi profesional adalah kemampuan dalam penguasaan mata pelajaran tata bidang studi yang di ajarkan dan terpaku dengan kemampuan mengajarnya sekaligus sehingga guru itu memiliki wibawa akademis.

3. Kompetensi kemasyarakatan adalah kemampuan yang berhubungan dengan bentuk partisipasi sosial seorang guru dalam kehidupan sehari-hari di masyarakat tempat 
iabekerja, baik formal maupun informal.

\section{Kompetensi Kepemimpinan}

Organisasi profesi membutuhkan unit kerja yang terbangun secara sistematik.Kemampuan itu dapat dilakukan oleh kelompok profesi guru yang mempunyai

kepemimpinan.Kepemimpinan

merupakan salah satu kompetensi yang perlu guru kuasai.Hal ini untuk menunjang martabat kode etik profesi guru. Gurumembutuhkan kompetensi kepemimpinan untuk menjalankan peran dalam organisasi sekolah. Kepemimpinan dapat mempengaruhi moral, kepuasan kerja, keamanan, kualitas kehidupan kerja dan terutama tingkat prestasi suatu organisasi.Kemampuan kepemimpinan dalam pengarahan adalah faktor penting efektifitas pengelolaan.Kepemimpinan adalah suatu upaya penggunaan jenis pengaruh bukan paksaan atau concersive untuk memotivasi orang-orang dalam mencapai tujuan tertentu. Adapun kepemimpinan adalah kegiatan dalam mempengaruhi orang lain untuk bekerja keras dengan penuh kemauan untuk tujuan kelompok (Moch. Uzer Usman, 2005: 17).

Menurut M.H Matondang (2009: 4) mengutip Peter F. Drucker, pemimpin seharusnya memiliki minimal 3 bidang kemampuan atau kompetensi yaitu:

1. Kemampuan pribadi, memiliki integritas tinggi, memiliki visi yang jelas, intelegensia tinggi, kreatif dan inovatif, tidak mudah merasa puas, fleksibel dan memiliki kematangan jiwa, sehat jasmani dan rohani, wibawa dan kharismatik, mempunyai idealisme dan cinta tanah air.

2. Kemampuan kepemimpinan (Leadership Mastery), memiliki kemampuan memotivasi orang lain, membuat keputusan yang cepat dan tepat, mempengaruhi orang lain, mengelola konflik, berorganisasi, memimpin tim kerja, mengendalikan sstress dan keterampilan berkomunikasi.

3. Kemampuan berorganisasi (Organizational Mastery), yang memiliki kemampuan mengembangkan organisasi, manajemen startegik, meraih peluang,mengadakan pengkaderan generasi penerus, memahami aspek makro dan mikro ekonomi dan keterampilan operasional.

Kadar kompetensi kepemimpinan seseorang dapat dipelajari melalui 4 (empat) tingkatan kemampuan yaitu: (1)seseorang tidak memiliki pengetahuan banyak tentang kopentensi kepemimpinan, dan tidak peka untuk mengembangkan kompetensi tersebut, mungkin karena mereka tidak pernah mencoba menjadi pemimpin;(2) seseorang menjadi sadar apa yang diperlukan untuk mengerjakan sesuatu secara baik, tetapi masih merupakan kompetensi yang masih bersifat personal. Dengan berlatih seseorang akan lebih peka dan sadar tentang hal yang benar juga penting dilakukan untuk kemudian secara gradual diubah menjadi kompetensi kepemimpinan;(3) kepemimpinan atau kompetensi akan sesuatu hal menjadi suatu kenikmatan yang sempurna. Anda akan menerima feed back positif dari kemampuan skill dan kepekaan tentang seberapa baik keadaan seseorang yang akan segera berlanjut ke tingkat empat, dan (4) kemampuan kepemimpinan atau skill menjadi bagian diri seseorang dan akan tampak secara alami. Seseorang yang yang dilahirkan dari pada bagaimana ia dibentuk atau bahwa seseorang pemimpin alami, itu berarti orang tersebut dapat langsung beroperasi 
menjadi pemimpin tanpa melalui tahapan (M.H Matondang, 2009: 9).

Kepemimpinan merupakan seni menggerakkan organisasi.Organisasi profesi membutuhkan kekuatan keahlian diri guru dalam menggerakkan secara alami dan taktis.Untuk itu menjadi masalah dasar kepemimpinan.Profesi guru membutuhkan dasar-dasar kepemimpinan agar terjadi siklus organisasi berjenjang.Hakikat organisasi profesi guru terletak kemampuan guru meletakkan kepemimpinan sebagai landasan pengelolaan.Oleh karena itu karakteristik kepemimpinan mempunyai tanggung jawab dalam pengembangan profesi guru.Seorang pemimpin yang baik harus memiliki beberapa karakteristik sebagai berikut(Kartini Kartono, 1988: 69).

1. Tanggung jawab seimbang.

2. Model peranan positif.

3. Memiliki keterampilan komunikasi yang baik.

4. Memiliki pengaruh positif.

5. Mempunyai kemampuan untuk menyakinkan orang lain

Seorang pemimpin mengharuskan

karakteristik nilai dan sikap yang melekat pada diri guru.Hal ini merupakan pembeda dengan profesi lain.Guru mengharuskan kemampuan jiwa kepemimpinan yang dapat ditunjukkan dalam kegiatan komunikasi yang bersinergi di lembaga pendidikan.Lembaga pendidikan yang handal memberikan tempat pada seorang guru.Guru yang dapat berperan adalah guru yang memberikan arti positif bagi organisasi yang dapat bersinergi antar guru.Oleh karena itu dapat mendudukkan peranan guru secara makro maupun mikro.Kemampuannya mesti mendapatkan perhatian jika mengharapkan organisasi sekolah visioner.
Organisasi yang visioner merupakan ciri adanya kepemimpinan yang aktif.Keaktifan kepemimpinan membutuhkan ruang lingkup tugas yang menjiwai nilai-nilai kepemimpinan. Karakteristik nilai-nilai kepemimpinan dapat diukur melalui ciri berikut ini:

1. Pemimpin menentukan dan mengungkapkan misi organisasi profesi guru.

2. Pemimpin menetapkan tujuan, prioritas dan standar.

3. Pemimpin lebih memandang kepemimpinan sebagai tanggung jawab dari pada suatu hak istimewa dari suatu kedudukan.

4. Pemimpin bekerja dengan orangorang yang berpengetahuan dan tangguh, serta memberikan kontribusi kepada organisasi.

5. Pemimpin memperoleh kepercayaan, respek dan integritas.

\section{Model pendekatan analisis swot}

Pembahasan lima kompetensi dan ragam pembahasan kompetensi mempunyai relasi dengan guru di lembaga pendidikan Islam. Hal ini yang membedakan dengan lembaga pendidikan lainnya. Guru PAI mempunyai pembeda dengan guru mata pelajaran lainnya yang terletak pada aspek nilai-nilai transendental yang cara menjelaskan bersifat doktrin dan dan tekstual. Guru PAI bertugas mengembangan keahlian saintifik juga untuk menunjukkan kapasitas keilmuan. Sebagaimana pendapat Imam Suprayogo yang tertulis bahwa lulusan kampus ini kususnya yang membidani masalah keguruan, yaitu FITK harus melahirkan ulama' yang intelek dan intelek yang ulama' (Imam Suprayogo, 2004: 113).

Gurumempunyai tanggung jawab besar terhadap peningkatan kompetensi yang sudah dirumuskan dalam undang- 
undang guru dan aturan-aturan lainnya. Bentuk aturan itu merupakan wujud komitmen pemerintah terhadap dunia pendidikan meskipun di dalam di fakta kehidupan masyarakat pendidikan masih banya dijumpai hambatan pelaksanaan peranturan tersebut. Seorang guru semestinya menunjukkan komepetensinya dasar bagi pendidik ditentukan oleh tingkat kepekaannya dari bobot potensi dasar dan kecenderungan yang dimilikinya.Hal tersebut karena potensi itu merupakan tempat dan bahan untuk menjawab semua tantangan yang datang dari luar dirinya.

Gurusebagai pendidik melakukan rekayasa pembelajaran berdasarkan kurikulum yang berlaku. Dalam tindakan tersebut guru menggunakan asas pendidikan maupun teori pendidikan. Guru membuat desain instruksional mengacu pada desain ini para peserta didik menyusun program pembelajaran di rumah dan bertanggung jawab sendiri atas jadwal belajar yang dibuatnya. Sementara itu peserta didik sebagai pembelajar di sekolah memiliki kepribadian, pengalaman dan tujuan.Peserta didik tersebut mengalami perkembangan jiwa sesuai dengan asas emansipasi dirinya menuju keutuhan dan kemandirian.

Kapasitas pengembangan

kompetensi guru perlu memperhatikan kepribadian dan kemandirian.Dua hal tersebut menjadi dasar kualitas guru yang senantiasa meningkatkan diri.Tenaga kependidikan sebagai perencana pengembangan kompetensi guru berdasarkan kaidah-kaidah perencanaan.Perencanaannya adalah ketajaman guru sebagai bagian dari evaluator pendidikan. Evaluasi merupakan suatu proses penaksiran terhadap pengembangan tujuan pendidikan (Oemar Hamalik, 1982: 106). Tujuan pendidikan yang menyangkut guru adalah berkaitan dengan jenjang pendidikan formal, spesifikasi bidang keahlian, sertifikasi dan jenjang pengembangan karier.

Untuk mewujudkan

pengembangan kompetensi guru yang mendapatkan pemikiran, yaitu aspek (Syaiful Sagala, 2006: 113-122): (1) analisis kebutuhan dan perencanaan penyelenggaraan pendidikan; perencanaan pengelolaan perlengkapan dan fasilitas sekolah; (3) perencana sekolah pengguna perencanaan strategik; (4) siapa perencana pendidikan.

Analisis kebutuhan guru yang mempunyai kompetensi sesuai dengan bidang studi merupakan masalah pokok dalam peningkatan keguruan. Gurumempunyai tanggung jawab pelayanan dalam bidang akademik. Pelayanan akademik mengharuskan kemampuan guru mengetahui konsepkonsep keilmuan dan mempunyai keterampilan menerapkan di lembaga pendidikan.Hal ini menyangkut kebutuhan guru di dalam lembaga maupun guru di luar lembaga merupakan tanggung jawab struktur organisasi sekolah dan organisasi guru.Guru merupakan bagian dari sistem kelembagaan yang harus tertata sehingga perencanaan menjadi penting.Perencanaan sekolah berkewajiban memberikan data dan informasi yang akurat mengenai kebutuhan guru dan fasilitas yang melakat kepada guru untuk meningkatkan kinerjanya.Kebutuhan yang penting adalah menyangkut terhadap sarana pembelajaran agar lebih efektif dan produktif.

Pengembangan kompetensi guru membutuhkan manajemen untuk mencapai tujuan standar yang telah ditetapkan kebijakan pemerintah. Manajemen yang menyangkut pengorganisasian kompetensidianalisis dengan pendekatan teknik analisis SWOT. 
Analisis SWOT (strength, weakness, opportunity dan treatment) mencakup aspek: (1) identifikasi kelemahan (internal, kompetensi guru) dan ancaman (eksternal, kondisi SDM guru). (2) identifikasi kekuatan (internal) dan peluang (eksternal) yang diperkirakan cocok untuk mengatasi kelemahan dan ancaman yang telah diidentifikasi pada langkah pertama. (3) lakukan SWOT lanjutan setelah diketahui kekuatan, kelemahan, peluang dan ancaman yang telah diidentifikasi pada langkah pertama. (4) dasar-dasar pemikiran pemecahan yang direkomendasikan untuk menangani kelemahan dan ancaman, termasuk pemecahan masalah, perbaikan dan pengembangan lebih lanjut. identifikasi prioritas penanganan kelemahan dan ancaman itu, dan disusun suatu rencana tindakan untuk melaksanakan program penanganan.

Setelah melakukan analisis SWOT, berikutnya adalah melakukan langkahlangkah strategi yang dapat dilihat pada tabel berikut ini (Tobroni, 2007).

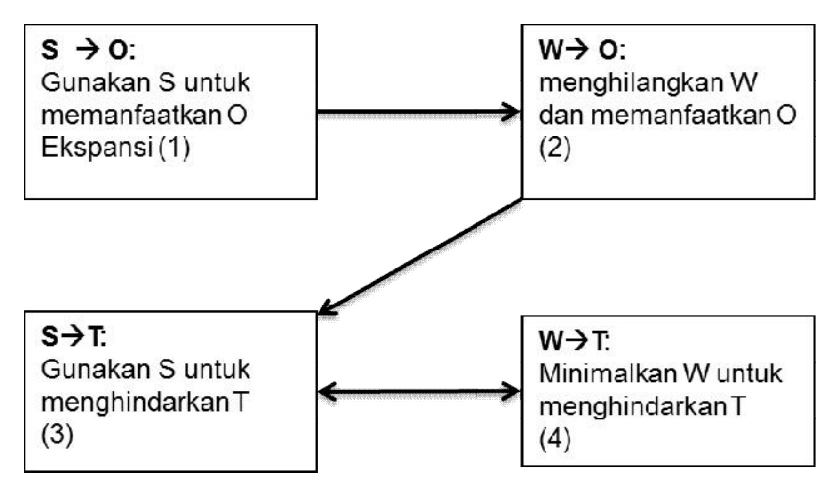

Dengan analisis SWOT tersebut diharapkan budaya akademik dapat melakukan langkah-langkah strategis.

1. Pendekatan SO. Inilah yang paling diharapkan, lima standar kompetensi guru dapatbersinergi dengan aktivitas guru dalam melaksanakan pengajaran, pembimbingan, pelatihan dan pengevaluasian. Strategi ini dibuat berdasarkan jalan pikiran perusahaan, yaitu dengan menggunakan seluruh kekuatan untuk memanfaatkan peluang.

2. Pendekatan WO. Yaitu cara mengeliminir kelemahan untuk selanjutnya mendayagunakan peluang. Kalau diharapkan seorang pedagang yang tidak punya modal tetapi ada kesempatan untuk meraup keuntungan, maka yang dilakukan adalah memfokuskan pada upaya mendapatkan keuntungan sambil berusaha mendapatkan modal. Bukan meratapi kelemahan sehingga peluang hilang. Hal ini terkait dengan kekuatan yang nampak apa di lembaga pendidikan setempat. Strategi ini diterapkan berdasarkan pemanfaatan peluang yang ada, dengan cara mengatasi kelemahan-kelemahan yang dimiliki.

3. Pendekatan ST. Yaitu dengan cara melakukan koordinasi untuk meningkatkan dan mendayagunakan kekuatan guna menetralisir, menghindari ancaman eksternal maupun internal atau merubah ancaman menjadi peluang. Dalam realita, apa yang diidentifikasi sebagai ancaman pada dasarnya belum tentu ancaman yang sesungguhnya. Strategi ini untuk menggunakan kekuatan yang dimiliki dengan cara menghindari ancaman. Jadi strategi ini diterapkan untuk menghindari kompetensi secara langsung.

4. Pendekatan WT. Yaitu meminimalkan kelemahan untuk menghindari ancaman. Strategi ini didasarkan pada kegiatan yang bersifat defensive dan ditujukan untuk meminimalkan kelemahan yang ada serta menghindari ancaman. 
Penutup

Kompetensi guru merupakan dasar untuk mengukur keterampilan pembelajaran dan kepribadian.Kedudukan guru mempunyai posisi penting dalam lembaga pendidikan karena kondisi guru mempunyai hubungan langsung dengan perkembangan pengetahuan peserta didik.Etos belajar peserta didik dapat dipengaruhi kapasitas guru. Guru mempunyai makna penting pada aspek pengajaran, pembinaan, pelatihan dan pengevaluasian yang mempengaruhi kualitas peserta didik.Keahlian guru mesti dapat dukungan sarana prasarana pembelajaran yang memadai. Sarana itu dapat berupa tempat belajar dan sarana alat teknologi pembelajaran. Guru mengharuskan penguasaan teknologi pembelajaran. Hal itu sebagai media guru dengan peserta didik.

Lima kompetensi guru adalah suatu ukuran yang ditetapkan dalam bentuk penguasaan pengetahuan dan berperilaku layaknya seorang guru untuk menduduki jabatan fungsional sesuai bidang tugas, kualifikasi dan jenjang pendidikan supaya mutu guru dapat diketahui. Standar kompetensi guru bertujuan mendapatkan jaminan kualitas guru dalam meningkatkan proses pembelajaran. Gurumerupakan kunci keberhasilan dalam pelaksanaan pengembangan sumber daya manusia. Dengan demikian, konsekwensi guru perlu memenuhi kualifikasi akademik, pengalaman pelatihan, pengalaman mengajar, perencanaan pembelajaran, penilaian atasan dan prestasi akademik. Pengembangan kompetensi guru akan berjalan secara baik manakala fungsifungsi manajemen dapat dijalankan oleh para guru.

\section{Daftar Pustaka}

Muhaimin. 2005.Pengembangan Kurikulum Pendidikan Agama Islam.Jakarta: GrafindoPersada. Raja

Muhaimin.2003. Wacana Pengembangan Pendidikan Islam.Yogyakarta: Pustaka Pelajar.

Syaefudin Saud, Udin. (Pengembangan Profesi Guru.Bandung : CV. Alfa Beta.

Rusman. 2010. Model-model Pembelajara dan Pengembangan Profesionalisme Guru. Bandung: Rajawali Pers.

Uno, Hamzah. 2012. Profesi Kependidikan. Jakarta: Bumi Aksara.

Kunandar. $2007 . \quad$ Guru Profesional:Implementasi

Kurikulum Tingkat Satuan Pendidkan Dan Sukses Dalam Sertifikasi Guru. Jakarta: Raja Grafindo Persada.

N.K, Roestiyah. 1989. Masalah-masalah Ilmu Keguruan. Jakarta: Bina Aksara.

Kunandar, Guru Profesional:Implementasi Kurikulum Tingkat Satuan Pendidkan Dan Sukses Dalam Sertifikasi Guru

Roqib, Moh. 2011. Kepribadian Guru sebagai Upaya Mengembangkan Kepribadian Guru yang Sehat di Masa Depan. Purwokerto: STAIN Purwokerto Press.

Daradjat, Zakiyah. 1995. Pendidikan Islam Dalam Keluarga dan Sekolah .Jakarta: Ruhama.

Anshori, 2015,Transformasi Pendidikan Islam.Jakarta: Gaung PersadaPress.

Uzer Usman, Muh. 2005. Menjadi Guru Profesional. Bandung: Remaja Rosdakarya.

An Nahlawi, Abdurahman. 1989. Ushulut Tarbiyatil Islamiyah wa Asalibuha, Terj. Herry Noer Ali. Bandung: CV. Diponegoro. 
Sanjaya, Whina. 2007. Strategi Pembelajaran Berorientasi Standar Proses Pendidikan. Jakarta: Prenada Media.

Hamalik, Oemar. 1982. Pengajaran Unit. Bandung: Alumni.

Hamalik, Oemar. 2002. Pendidikan Guru (Berdasarkan Pendekatan Kompetensi). Jakarta: Bumi Aksara.

Anshori. 2010. Transformasi Pendidikan Islam.Jakarta : Gaung Persada Press.

Mukhtar. 2003. Merambah Manajemen Baru, Jakarta: Misaka Galiza.

Usman, Moch. Uzer. 2005. Menjadi Guru Profesional. Bandung: PT. Remaja Rosdakarya.

M.H. Matondang, 2009, Kepemimpinan, Budaya Organisasi dan Manajemen Strategik. Jakarta : Pustaka.
Kartono, Kartini. 1988. Pemimpin dan Kepemimpinan. Jakarta: Rajawali.

Suprayogo, Imam. 2004. Memelihara Sangkar Ilmu (Refleksi Pemikiran dan Pengembangan UIN Malang). Malang: UIN Press Malang.

Sagala, Syaiful. 2006. Manajemen Strategik dalam Peningkatan Mutu Pendidikan. Bandung: Alfabeta.

Tobroni. 2007. International Seminar Islamic Education in Globalization Era: Challenges and Efforts in Reformulating Orientation Strategy and Curriculum under the Partnership of Faculty of Islamic Studies UMM. Malang: seminar Internasional. 


\section{Indeks}

Ary ginanjar agustian, 28

Dosen, 7, 8, 11, 14, 16, 18, 26, 48, 56, 70,71

Guru, 25, 69, 71, 72, 73, 74, 75, 76, 77, $78,79,80,83,84,85,87,88$

Kepemimpinan

Kepemimpinan spiritual, 27, 28, 29, $31,32,33,34,36,37,38,39,40$

Kompetensi, 10, 14, 15, 17, 19, 69, 70, $71,72,73,74,75,76,77,78,79,80$, $82,83,84,85,86,87$

Lembaga pendidikan islam, 45, 46, 54, $55,56,59$

Madrasah, 43, 44, 46, 49, 50, 52, 56, 55

Mahasiswa, 4, 6, 7, 8, 9, 13, 16, 17, 18, $19,20,21,22,23,25,27,28,29,31$, $32,34,35,36,37,38,39,40$
Manajemen, 1, 2, 3, 4, 5, 6, 7, 8, 9, 10, $12,13,15,19,32,33,34,35,44,46$, $47,48,49,50,51,52,53,54,55,69$, $83,86,87$

Manajemen, 1, 44, 52, 53, 69

Muhammad, 28, 35, 41, 59, 61, 66, 67

Pendidikan, 1, 2, 3, 4, 5, 6, 7, 8, 9, 10, $12,13,14,16,17,18,19,20,21,22$, $23,24,25,28,33,41,44,46,47,48$, $49,51,52,53,54,55,56,57,58,59$, $60,67,69,71,72,73,74,75,76,78$, $80,84,85,86,87$

Perguruan tinggi, 1, 12

Pesantren, 27, 29, 33, 37, 38, 39, 40, 41, $42,43,44,45$

Sertifikasi, 18, 87

Swot, 24, 86

Universitas, 1, 3, 7, 23, 38 